\title{
Effects of nitrogen application and planting density on growth and yield of Sesbania pea grown in saline soil
}

\author{
Xiaoqian Guo ${ }^{1,2}$, Guanglong $\mathrm{Zhu}^{1}$, Xiurong $\mathrm{Jiao}^{1}$ and \\ Guisheng Zhou ${ }^{1,2,3, *}$ \\ ${ }^{1}$ Joint International Laboratory of Agriculture and Agri-Product Safety of Ministry of Education of China, Yangzhou University, \\ Yangzhou 225009, Jiangsu Province, China \\ ${ }^{2}$ Jiangsu Provincial Key Lab of Crop Genetics and Physiology, Yangzhou University, Yangzhou 225009, Jiangsu Province, China \\ ${ }^{3}$ Jiangsu Co-Innovation Center for Modern Production Technology of Grain Crops, Yangzhou University, Yangzhou 225009, China
}

Planting density and nitrogen $(\mathrm{N})$ application rate are the two major factors affecting crop productivity. The present study was carried out to evaluate the effects of $\mathrm{N}$ application rate and planting density on the growth and yield characteristics of Sesbania pea in saline soil. Two planting densities (D1: 120,000 plants $\mathrm{ha}^{-1}$ and D2: 200,000 plants $\mathrm{ha}^{-1}$ ) and three $\mathrm{N}$ application rates (N1: 0, N2: 180 and N3: $360 \mathrm{~kg} \mathrm{ha}^{-1}$ ) were applied in this study. The higher planting density decreased plant height, root length, pod number per plant and seed number per pod, but increased dry weight, $N$ uptake and total seed yield. Increasing $N$ application rate promoted plant height, SPAD reading, dry weight, pod number per plant, seed number per pod, seed yield and $N$ uptake, whereas further increase in nitrogen rate played only a minor role in growth and yield (except plant height and SPAD reading) at D1. Moreover, planting density and $N$ application rate had no significant effects on 1000-seed weight. According to the present study, D1 combined with $\mathrm{N} 2$ is an effective strategy to increase individual growth of Sesbania pea in saline soil, whereas D2 combined with $N 3$ is the effective strategy for total seed yield.

Keywords: Nitrogen application, planting density, saline soil, Sesbania pea.

SESBANIA pea (Sesbania cannabina (Retz.) Poir.) is a rapidly growing annual herbal shrub that is widely adaptable to adverse climatic conditions such as high salinity, drought, waterlogging and so on ${ }^{1}$. It grows extensively in the tropical regions of Asia, Australia and Africa as a green manure crop to improve soil fertility and reclaim soils contaminated by heavy metals ${ }^{2,3}$. In China, Sesbania pea has been planted in the hills, ditches and wetlands of the Yangtze River region and introduced into the Yellow River Delta to increase soil fertility and reduce soil salinity ${ }^{4}$. Sesbania is also a good feed for poultry, livestock and fish. The gum produced from Sesbania seeds is

*For correspondence. (e-mail: gszhou@yzu.edu.cn) highly water-soluble and widely used in oil production, mining and metallurgy, medicine and pesticide, and daily chemicals as well as textile and dyeing industry ${ }^{5}$. At present, Sesbania pea is mainly cultivated as a green manure crop and functional values of the seeds are far from being fully explored.

As mentioned in a previous study, crop yield typically showed a curvilinear response to plant densities or nitrogen fertilizer rates, and it reached a maximum level at the optimal plant density or nitrogen fertilizer application rate $^{6}$. Normally, planting density is one of the most basic and effective agronomic factors affecting crop productivity and is highly dependent on soil fertility, cultivar, climatic conditions and farming system ${ }^{7}$. Nasto et al. ${ }^{8}$ reported that increasing planting density to a reasonably high level led to higher yield $\left(\mathrm{kg} \mathrm{ha}^{-1}\right)$ of bell pepper. Crops planted at suitable low planting densities can produce more branches and pods per plant. With the increase in planting density, the decrease in individual plant productivity is related to decrease in the number of branches and pods per plant $^{9-11}$. In fact, changes in planting density can affect crop morphology, alter the ability of plants to capture resources (nutrients, sunlight, space, etc.) and induce different yield responses to nitrogen fertilizer ${ }^{1-14}$.

Nitrogen is considered one of the essential macronutrients required by the plants for growth, development and production ${ }^{15}$. Optimizing nitrogen application is one of the main ways to increase crop yield and achieve food and environment security ${ }^{16}$. Almost all surveys showed that nitrogen fertilizer at suitable rates increased seed yield substantially, even under diverse and contradicting conditions $^{17}$. Bani-Saeedi ${ }^{18}$ reported that nitrogen produced higher seed yield per hectare by reducing flower shedding and sequentially affecting 1000-seed weight, increasing silique number per unit area and decreasing seed number per silique. Tumbare and Niikam ${ }^{19}$ noticed that nitrogen fertilizer increased fruit weight, yield and fruit number of chilli peppers. As one of the important contributing factors to high seed yield, nitrogen fertilizer can effectively control the number of pods per plant ${ }^{9-11}$. 
However, excessive use of nitrogen fertilizer can lead to higher production costs, increase the risk of nitrate leaching and water pollution, and reduce nitrogen use efficiency $^{20,21}$.

Planting density and nitrogen application rate can have an interactive effect on crop growth and productivity. Majnoun-Hosseini et al. ${ }^{22}$ and Mobasser et al. $^{23}$ reported that plant height increased as planting space and use of nitrogen fertilizer decreased. Fathi et al. ${ }^{24}$ suggested that increasing nitrogen fertilizer and planting density can boost seed yield in rapeseed. However, there is little knowledge available on the effects of planting density and nitrogen application rate on the growth and physiology, and yield of Sesbania grown in saline soil. This is of critical importance for developing a strategy to increase Sesbania production in such soils. Keeping this in mind, the objectives of the present study were to evaluate the effects of planting density and nitrogen application rate on growth, physiology and yield of Sesbania pea, and to explore the optimal combination of planting density and nitrogen application rate for Sesbania production in saline soil.

\section{Materials and methods}

\section{Site description and treatment}

A field study was conducted in the Coastal Forest Farm of Dafeng, Dafeng town $\left(33^{\circ} 20^{\prime} \mathrm{N}, 120^{\circ} 47^{\prime} \mathrm{E}\right)$, Yancheng City, Jiangsu Province, China from April to October 2017, which provided Sesbania pea seeds. Before planting, soil samples were collected in the surface layer $(0$ $20 \mathrm{~cm}$ ) at the site to determine the physical and chemical soil properties. Soil total N was measured using the Kjeldahl method ${ }^{25}$. Soil Olsen-P was determined following the method of Page et al. ${ }^{26}$. Soil available $\mathrm{K}$ was measured according to McLean and Watson ${ }^{27}$. Soil organic matter was determined using the method of Tiessen and Moir $^{28}$. Soil pH was determined following the method of Hendershot et $a{ }^{29}{ }^{29}$. Salt content of soil was measured according to $\mathrm{Lu}^{30}$. Experimental field had loamy soil, with a textural class of clay loam and the initial fertility status of $\mathrm{N}=0.72 \mathrm{~g} \mathrm{~kg}^{-1}, \quad P=1.45 \mathrm{mg} \mathrm{kg}^{-1}, \quad \mathrm{~K}=279 \mathrm{mg} \mathrm{kg}^{-1}$, organic matter of $19.75 \mathrm{~g} \mathrm{~kg}^{-1}$, $\mathrm{pH}$ of 8.8 and salt content of $1.68 \mathrm{~g} \mathrm{~kg}^{-1}$.

The experiment was a split-plot design using a randomized complete block arrangement with three replications. The total experimental area was $259.2 \mathrm{sq}$. m, and the size of each plot was $1.2 \times 12 \mathrm{~m}$ (width $\times$ length). The treatments consisted of planting density at two levels $\left(\mathrm{D} 1=120,000\right.$ plants $\mathrm{ha}^{-1}$ and D2 $=200,000$ plants $^{-1}$ ) as the main plots and $\mathrm{N}$ application rate at three levels $\left(\mathrm{N} 1=0, \mathrm{~N} 2=180\right.$ and $\mathrm{N} 3=360 \mathrm{~kg} \mathrm{ha}^{-1}$ ) as subplots. Urea containing $46 \% \mathrm{~N}$ was used as the nitrogen source in two split doses: $50 \%$ at sowing and $50 \%$ at 77 days after planting (DAP). In addition to the nitrogen, calcium superphosphate was applied at $120 \mathrm{~kg} \mathrm{ha}^{-1}$ of $\mathrm{P}_{2} \mathrm{O}_{5}$ for all treatments in equal proportion at planting and 77 DAP.

Sesbania pea seeds were presoaked in $404.2 \mu \mathrm{m} \mathrm{MGA}_{3}$ solution $6 \mathrm{~h}$ and sowed on 26 April 2017. At 21 DAP, all the plots were thinned to the target planting density. During the whole growing season, all the other field managements, including herbicide application, pest and disease control followed the local recommendations.

\section{Observations and measurements}

Growth characteristics: At four dates after planting, including 47, 77, 107 and 138 DAP, 10 representative plants were randomly sampled from each plot to measure growth parameters. The roots of each plant were dug out from the soil with a spade and washed with tap water to measure the root characteristics. Plant height and root length were measured with a standard metre ruler. All plant samples were oven-dried at $105^{\circ} \mathrm{C}$ first for $30 \mathrm{~min}$ to deactivate the enzymes and then at $80^{\circ} \mathrm{C}$ until they reached a constant weight for biomass determination.

Physiological characteristics: Leaf chlorophyll content was measured using a hand-held chlorophyll metre (SPAD-502) in the middle portion of a leaf at 47, 77, 107 and 138 DAP. Nine leaf SPAD readings were averaged to represent the mean SPAD readings of each leaf, and six leaves were measured at each plot. The dried samples were ground to measure plant $\mathrm{N}$ concentration using the micro-Kjeldahl method ${ }^{31}$.

Seed yield and yield components: At maturity, 10 samples were hand harvested randomly from each plot. All plant samples were dried in an oven at $105^{\circ} \mathrm{C}$ first for $30 \mathrm{~min}$ to deactivate the enzymes and then $80^{\circ} \mathrm{C}$ until they reached a constant weight. The following observations and measurements were made for each plant: 1000-seed weight, seed number per pod and pod number per plant.

One square metre area was selected randomly to measure total seed yield.

Statistical analysis: The experiment was designed with two factors (two planting densities and three nitrogen application rates) and arranged in a completely randomized design with three replicates. The collected data of each variable were subjected to analysis of variance (ANOVA) using the statistical package of SAS 9.4. Significant differences in means between the treatments were compared by the protected least significant difference (LSD) procedure at $5 \%$ probability level, as described by Gomez and Gomez $^{32}$.

\section{Results}

Both planting density and nitrogen application rate had significant effects on plant height (Table 1). Plant height 
Table 1. Effect of planting density and nitrogen application rate on the height, root length and SPAD reading of Sesbania plants grown in saline soils

\begin{tabular}{|c|c|c|c|c|c|c|c|c|c|c|c|c|c|}
\hline \multirow{3}{*}{$\begin{array}{l}\text { Experimental } \\
\text { factor }\end{array}$} & \multirow{3}{*}{$\begin{array}{c}\text { Experimental } \\
\text { level }\end{array}$} & \multicolumn{4}{|c|}{ Height (cm) } & \multicolumn{4}{|c|}{ Root length (cm) } & \multicolumn{4}{|c|}{ SPAD reading } \\
\hline & & \multicolumn{4}{|c|}{ DAP } & \multicolumn{4}{|c|}{ DAP } & \multicolumn{4}{|c|}{ DAP } \\
\hline & & 47 & 77 & 107 & 138 & 47 & 77 & 107 & 138 & 47 & 77 & 107 & 138 \\
\hline \multirow[t]{2}{*}{ Density (plants ha ${ }^{-1}$ ) } & 120,000 & 25.0 & 93.7 & 218.9 & 270.7 & 5.8 & 13.9 & 27.7 & 31.5 & 46.6 & 50.8 & 57.2 & 53.9 \\
\hline & 200,000 & 23.1 & 86.6 & 202.7 & 250.3 & 4.9 & 11.2 & 22.1 & 26.7 & 45.6 & 50.1 & 57.9 & 54.8 \\
\hline \multirow[t]{4}{*}{ Nitrogen $\left(\mathrm{kg} \mathrm{ha}^{-1}\right)$} & 0 & 20.8 & 82.6 & 198.9 & 246.3 & 5.3 & 12.0 & 24.8 & 28.5 & 44.1 & 49.1 & 54.4 & 51.3 \\
\hline & 180 & 24.4 & 92.1 & 210.2 & 261.5 & 5.7 & 12.3 & 25.1 & 29.5 & 47.0 & 50.9 & 57.8 & 54.5 \\
\hline & 360 & 26.9 & 95.6 & 223.3 & 273.9 & 5.2 & 12.4 & 24.9 & 29.4 & 47.2 & 51.4 & 60.3 & 57.3 \\
\hline & $\operatorname{LSD}_{(0.05)}$ & 1.5 & 8.7 & 15.0 & 7.3 & 0.8 & 1.8 & 2.0 & 2.2 & 1.9 & 1.7 & 1.6 & 3.8 \\
\hline Density & $* *$ & $*$ & $* *$ & $* *$ & $*$ & $* *$ & $* *$ & $* *$ & ns & ns & ns & ns & \\
\hline Nitrogen & $* *$ & $*$ & $* *$ & $* *$ & $\mathrm{~ns}$ & ns & $\mathrm{ns}$ & $\mathrm{ns}$ & $* *$ & $*$ & $* *$ & $* *$ & \\
\hline
\end{tabular}

DAP, Days after planting; *Significant difference at $P \leq 0.05 ; * *$ Significant difference at $P \leq 0.01$; ns, Non-significant difference.

Table 2. Effects of planting density and nitrogen application rate on the dry weight of leaf, stem and root of Sesbania plants grown in saline soils

\begin{tabular}{|c|c|c|c|c|c|c|c|c|c|c|c|c|c|}
\hline \multirow{3}{*}{$\begin{array}{l}\text { Density } \\
\left(\text { plants } \mathrm{ha}^{-1}\right)\end{array}$} & \multirow{3}{*}{$\begin{array}{l}\text { Nitrogen } \\
\left(\mathrm{kg} \mathrm{ha}^{-1}\right)\end{array}$} & \multicolumn{4}{|c|}{ Dry leaf weight $\left(\mathrm{kg} \mathrm{ha}^{-1}\right)$} & \multicolumn{4}{|c|}{ Dry stem weight $\left(\mathrm{kg} \mathrm{ha}^{-1}\right)$} & \multicolumn{4}{|c|}{ Dry root weight $\left(\mathrm{kg} \mathrm{ha}^{-1}\right)$} \\
\hline & & \multicolumn{4}{|c|}{ DAP } & \multicolumn{4}{|c|}{ DAP } & \multicolumn{4}{|c|}{ DAP } \\
\hline & & 47 & 77 & 107 & 138 & 47 & 77 & 107 & 138 & 47 & 77 & 107 & 138 \\
\hline \multirow[t]{2}{*}{120,000} & 0 & 17.7 & 180 & 1072 & 684 & 14.8 & 348 & 3000 & 4154 & 3.9 & 74 & 415 & 720 \\
\hline & 180 & 20.7 & 317 & 1474 & 1072 & 19.7 & 590 & 4010 & 7159 & 5.2 & 127 & 623 & 928 \\
\hline \multirow[t]{4}{*}{200,000} & 0 & 28.4 & 205 & 1425 & 916 & 23.8 & 460 & 4075 & 6014 & 5.7 & 98 & 588 & 972 \\
\hline & 180 & 30.2 & 369 & 1489 & 1316 & 25.2 & 632 & 4727 & 7575 & 6.4 & 127 & 758 & 1120 \\
\hline & 360 & 31.1 & 460 & 1836 & 1605 & 30.4 & 791 & 5130 & 10,840 & 8.1 & 196 & 905 & 1233 \\
\hline & $\operatorname{LSD}_{(0.05)}$ & 1.8 & 56.9 & 197.6 & 183.2 & 2.5 & 100.0 & 367.1 & 756.6 & 1.1 & 17.4 & 103.6 & 110.4 \\
\hline Density & & $* *$ & $* *$ & $* *$ & $* *$ & $* *$ & $* *$ & $* *$ & $* *$ & $* *$ & $* *$ & $* *$ & $* *$ \\
\hline Nitrogen & & $* *$ & $* *$ & $* *$ & $* *$ & $* *$ & $* *$ & $* *$ & $* *$ & $* *$ & $* *$ & $* *$ & $* *$ \\
\hline Density $\times$ nit & & $*$ & $* *$ & $* *$ & $* *$ & $* *$ & $* *$ & $\mathrm{~ns}$ & $* *$ & $*$ & $* *$ & $* *$ & $*$ \\
\hline
\end{tabular}

DAP, Days after planting; *Significant difference at $P \leq 0.05 ; *$ Significant difference at $P \leq 0.01$; ns, Non-significant difference.

at 200,000 plants $\mathrm{ha}^{-1}$ was lower than that at 120,000 plants $\mathrm{ha}^{-1}$. With increased nitrogen application rate, plant height generally increased and maximum height was recorded at $360 \mathrm{~kg} \mathrm{ha}^{-1}$ level on most sampling dates. At 77 and 107 DAP, maximum plant height was obtained with $\mathrm{N}$ at 180 and $360 \mathrm{~kg} \mathrm{ha}^{-1}$ levels. During the whole growth period, plant height increased rapidly before 107 DAP and then tended to be gentle. At 107 DAP, plant height was decreased by $7.4 \%$ at 200,000 plants $\mathrm{ha}^{-1}$ level, and increased by $12.3 \%$ with $\mathrm{N}$ at $360 \mathrm{~kg} \mathrm{ha}^{-1}$ level.

Density had significant effects on root length (Table 1). At 120,000 plants ha ${ }^{-1}$, root length was higher than that at 200,000 plants $\mathrm{ha}^{-1}$. Although root length showed an increasing trend with the application of nitrogen fertilization, the effects of nitrogen on root length were not statistically significant. Similar to plant height, root length increased gradually throughout the whole growth period. At 107 DAP, root length decreased by $20.2 \%$ at 200,000 plants ha ${ }^{-1}$ level.
The effects of planting density on SPAD value were not significant, whereas nitrogen had significant effects on SPAD values (Table 1). SPAD values generally showed an increasing trend with increasing nitrogen application rate, but the increase had no significant difference between $\mathrm{N}$ at 180 and $360 \mathrm{~kg} \mathrm{ha}^{-1}$ levels, except for that at 107 DAP. The highest SPAD value was observed with $\mathrm{N}$ at $360 \mathrm{~kg} \mathrm{ha}^{-1}$ level, followed by 180 and $0 \mathrm{~kg} \mathrm{ha}^{-1}$ levels. Before 107 DAP, SPAD value had an increasing trend and then decreased slightly. At 107 DAP, SPAD value increased by $10.8 \%$ with $\mathrm{N}$ at $360 \mathrm{~kg} \mathrm{ha}^{-1}$ level.

The effects of planting density and nitrogen application rate on leaf dry weight, stem dry weight and root dry weight were significant (Table 2). They were all higher at 200,000 plants ha $\mathrm{a}^{-1}$ than at 120,000 plants $^{-1}$. At 120,000 plants $\mathrm{ha}^{-1}$ level, with increase in nitrogen application rate all the above parameters generally increased first and then decreased. However, at 200,000 plants ha ${ }^{-1}$ 
Table 3. Effect of planting density and nitrogen application rate on $\mathrm{N}$ uptake of leaf, stem, root and seeds of Sesbania plants grown in saline soil

\begin{tabular}{|c|c|c|c|c|c|}
\hline $\begin{array}{l}\text { Density } \\
\left(\text { plants ha }{ }^{-1}\right)\end{array}$ & $\begin{array}{l}\text { Nitrogen } \\
\left(\mathrm{kg} \mathrm{ha}^{-1}\right)\end{array}$ & $\begin{array}{l}\text { Leaf } \mathrm{N} \text { uptake } \\
\qquad\left(\mathrm{kg} \mathrm{ha}^{-1}\right)\end{array}$ & $\begin{array}{l}\text { Stem N uptake } \\
\left(\mathrm{kg} \mathrm{ha}^{-1}\right)\end{array}$ & $\begin{array}{l}\text { Root N uptake } \\
\quad\left(\mathrm{kg} \mathrm{ha}^{-1}\right)\end{array}$ & $\begin{array}{l}\text { Seed N uptake } \\
\left(\mathrm{kg} \mathrm{ha}^{-1}\right)\end{array}$ \\
\hline \multirow[t]{3}{*}{120,000} & 0 & 9.2 & 22.3 & 3.7 & 13.8 \\
\hline & 180 & 21.9 & 62.6 & 6.1 & 38.5 \\
\hline & 360 & 17.8 & 45.8 & 5.7 & 30.8 \\
\hline \multirow[t]{4}{*}{200,000} & 0 & 10.9 & 28.6 & 4.3 & 14.7 \\
\hline & 180 & 20.0 & 50.7 & 6.2 & 34.2 \\
\hline & 360 & 32.4 & 90.2 & 8.2 & 50.3 \\
\hline & $\operatorname{LSD}_{(0.05)}$ & 3.8 & 8.1 & 0.7 & 3.9 \\
\hline Density & & $* *$ & $* *$ & $* *$ & $* *$ \\
\hline Nitrogen & & $* *$ & $* *$ & $* *$ & $* *$ \\
\hline Density $\times$ nitrogen & & $* *$ & $* *$ & $* *$ & $* *$ \\
\hline
\end{tabular}

*Significant difference at $P \leq 0.05 ; *$ Significant difference at $P \leq 0.01$; ns, Non-significant difference.

level, leaf dry weight, stem dry weight and root dry weight increased with increasing nitrogen application rate. The maximum weight was observed at 200,000 plants ha ${ }^{-1}$ with $\mathrm{N}$ at $360 \mathrm{~kg} \mathrm{ha}^{-1}$ level. Leaf dry weight increased before 107 DAP and showed a sharp decline after 107 DAP. However, stem dry weight and root dry weight increased during the growth period. Among the three sampling sites, maximum dry weight was observed in the stem, followed by leaf and root. At 107 DAP, leaf dry weight increased by $17.7 \%$, stem dry weight by $31.1 \%$ and root dry weight by $25.1 \%$ at 120,000 plants $\mathrm{ha}^{-1}$ with $\mathrm{N}$ at $180 \mathrm{~kg} \mathrm{ha}^{-1}$ level. While at 200,000 plants ha ${ }^{-1}$ with $\mathrm{N}$ at $360 \mathrm{~kg} \mathrm{ha}^{-1}$ level, leaf dry weight increased by $28.8 \%$, stem dry weight by $25.9 \%$ and root dry weight by $53.9 \%$.

Planting density and nitrogen application rate had significant effects on $\mathrm{N}$ uptake (Table 3). Density at 200,000 plants ha ${ }^{-1}$ level resulted in higher $\mathrm{N}$ uptake than that at 120,000 plants ha ${ }^{-1}$ level. At 200,000 plants ha ${ }^{-1}$ level, $\mathrm{N}$ uptake increased with increase in nitrogen application rate and maximum $\mathrm{N}$ uptake was observed with $\mathrm{N}$ at $360 \mathrm{~kg} \mathrm{ha}^{-1}$ level. At 120,000 plants ha ${ }^{-1}$ level, $\mathrm{N}$ uptake generally reached a maximum with $\mathrm{N}$ at $180 \mathrm{~kg} \mathrm{ha}^{-1}$ and then decreased, except for root $\mathrm{N}$ uptake. The higher nitrogen application rate resulted in lower root $\mathrm{N}$ uptake, but the decrease was not statistically significant at 120,000 plants ha ${ }^{-1}$ level. At 120,000 plants ha ${ }^{-1}$ with $\mathrm{N}$ at $180 \mathrm{~kg} \mathrm{ha}^{-1}$ level, leaf $\mathrm{N}$ uptake increased by $138.0 \%$, stem $\mathrm{N}$ uptake by $180.7 \%$, root $\mathrm{N}$ uptake by $64.9 \%$ and seed $\mathrm{N}$ uptake by $179.0 \%$. While at 200,000 plants $^{-1}$ with $\mathrm{N}$ at $360 \mathrm{~kg} \mathrm{ha}^{-1}$ level, leaf $\mathrm{N}$ uptake increased by $197.2 \%$, stem $\mathrm{N}$ uptake by $215.4 \%$, root $\mathrm{N}$ uptake by $90.7 \%$ and seed $\mathrm{N}$ uptake by $242.2 \%$. Planting density and nitrogen application rate had the greatest impact on stems, followed by seeds, leaves and roots.

The effects of density and nitrogen application on pod number per plant, seed number per pod and total seed yield were significant, but the effects on 1000-seed weight were not significant (Table 4). Pod number per plant and seed number per pod at 120,000 plants ha $^{-1}$ were higher than those at 200,000 plants $\mathrm{ha}^{-1}$, while total seed yield showed the opposite trend. At 120,000 plants $\mathrm{ha}^{-1}$ level, with increase in nitrogen application rate, seed numbers per pod and total seed yield reached maximum $\mathrm{N}$ at $180 \mathrm{~kg} \mathrm{ha}^{-1}$ level and then decreased; nitrogen at $180 \mathrm{~kg} \mathrm{ha}^{-1}$ level increased pod number per plant, whereas $\mathrm{N}$ at $360 \mathrm{~kg} \mathrm{ha}^{-1}$ level had no significant effect on pod number per plant. At 200,000 plants ha ${ }^{-1}$ level with increasing nitrogen application rate, these traits increased. Higher seed number per pod and total seed yield were recorded at both 180 and $360 \mathrm{~kg} \mathrm{ha}^{-1} \mathrm{~N}$. The highest pod number per plant was recorded at $360 \mathrm{~kg} \mathrm{ha}^{-1} \mathrm{~N}$. The highest total seed yield was reached at 200,000 plants ha ${ }^{-1}$ level combined with $\mathrm{N}$ at $360 \mathrm{~kg} \mathrm{ha}^{-1}$ level. Pod number per plant increased by $44.7 \%$, seed number per pod by $19.3 \%$ and total seed yield by $92.9 \%$ at 120,000 plants ha ${ }^{-1}$ with $\mathrm{N}$ at $180 \mathrm{~kg} \mathrm{ha}^{-1}$ level. Whereas at 200,000 plants ha ${ }^{-1}$ with $\mathrm{N}$ at $360 \mathrm{~kg} \mathrm{ha}^{-1}$ level, pod number per plant increased by $66.3 \%$, seed number per pod by $25.4 \%$ and total seed yield by $103.9 \%$.

\section{Discussion}

Planting density is a main factor determining the ability of crops to obtain resources ${ }^{11}$. Height of plant can generally be regarded as one of the indicators of plant vigour, which depends on the vigour and growth habits of the plant $^{15}$. In this study, increasing density decreased plant height and root length. The reduction in height and root length might be due to increased competition among plants for soil nutrients and climatic environmental resources ${ }^{33,34}$. Forbes and Watson ${ }^{35}$ and Samih $^{36}$ explained that competition for light, mineral nutrients and available water increases as plant population density increases. This study showed that the application of nitrogen resulted in increase in plant height. Similar results were also obtained by Amanullah et al. ${ }^{37}$, who found that plant 
Table 4. Effect of planting density and nitrogen application rate on seed yield and yield components of Sesbania plants grown in saline soil

\begin{tabular}{lccccc}
\hline $\begin{array}{l}\text { Density } \\
(\text { plants ha }\end{array}$ & $\begin{array}{c}\text { Nitrogen } \\
\left(\mathrm{kg} \mathrm{ha}^{-1}\right)\end{array}$ & $\begin{array}{c}\text { Pod number } \\
\text { per plant }\end{array}$ & $\begin{array}{c}\text { Seed number } \\
\text { per pod }\end{array}$ & $\begin{array}{c}\text { 1000-Seed } \\
\text { weight }(\mathrm{g})\end{array}$ & $\begin{array}{c}\text { Seed yield } \\
(\mathrm{kg} \mathrm{ha})\end{array}$ \\
\hline 120,000 & 0 & 84.3 & 26.9 & 13.8 & 3217.3 \\
& 180 & 122.0 & 32.1 & 15.4 & 6207.7 \\
200,000 & 360 & 104.7 & 28.9 & 14.2 & 4456.5 \\
& 0 & 68.0 & 24.0 & 14.2 & 3970.0 \\
& 180 & 99.0 & 28.1 & 15.2 & 7308.6 \\
Density & 360 & 113.1 & 30.1 & 13.9 & 8098.4 \\
Nitrogen & 11.0 & 3.2 & 2.0 & 1195.6 \\
Density $\times$ nitrogen & & $* *$ & $*$ & $\mathrm{~ns}$ & $* *$ \\
\hline
\end{tabular}

*Significant difference at $P \leq 0.05$. * indicates significant difference at $P \leq 0.01 ; \mathrm{ns}$, Non-significant difference.

height as well as biomass yield showed an increase with increasing nitrogen rate and the times of nitrogen application. Such results also confirm that $\mathrm{N}$ is essential for cell division and elongation ${ }^{38}$.

Chlorophyll is the major light-harvesting compound for photosynthesis. The present study showed that application of nitrogen increased the SPAD value. The contribution of inorganic fertilizers to chlorophyll content might be because nitrogen is a constituent of the chlorophyll molecule. In addition, nitrogen is the main component of all amino acids in lipids and proteins, and they act as structural compounds of the chloroplast ${ }^{39}$. Our results are in agreement with those of Loecke et al. ${ }^{40}$, who reported that chlorophyll meter readings of corn ear leaves responded positively to urea application rate at growth stage R1.

Regarding the effects of different nitrogen application rates and planting densities on agronomic traits and shoot development, Toghraei et al. ${ }^{41}$ showed that increased vegetative growth and development of shoots were followed by increased biomass yield as a result of the application of more nitrogen. In the present study, we found that dry weight was higher with 120,000 plants ha $^{-1}$. Higher planting density limits light penetration as well as dry matter accumulation ${ }^{33}$. Our results showed that the application of nitrogen increased plant dry weight. The improvement in dry weight might be due to the combination of nitrogen and plant matter produced during photosynthesis, such as protein, ascorbic acid, glucose and amino acids ${ }^{42}$. Similar results were also reported by Lin et $a{ }^{43}$, who found that increased $\mathrm{N}$ concentration promoted biomass accumulation. In addition, the increased height and root length allowed crops to improve the exploitation of environmental resources; while the higher chlorophyll content enhanced photosynthesis, accumulated more photosynthetic products and resulted in an increase in plant dry weight. However, at 120,000 plants ha ${ }^{-1}$ level, the highest nitrogen application rate had lower plant dry weight but still higher than the control. This may be attributed to the supply of nitrogen in excess of plant demand and a possibility exists for losing nitrogen by leaching and denitrification ${ }^{44}$.

Planting density and nitrogen application rate promoted pod numbers per plant and seed numbers per pod, and hence increased seed yield per plant. The significant effects of nitrogen on yield may be attributed to its cumulative stimulating effects on the vegetative growth characteristics that form the base for flowering and fruiting ${ }^{33}$. Khadem Hamzeh et al. ${ }^{45}$ showed that as the density increased, the number of pods per plant decreased. This might be due to the fact that competition for growth demand factors increased with increase of planting density and hence, the growth and development of single plant was less. However, Zandi et al. ${ }^{7}$ reported that different planting densities and nitrogen levels had no significant effects on the number of seed per pod of fenugreek. The difference might be due to the different species and planting density and nitrogen levels. Moreover, nitrogen levels and planting density did not affect 1000 -seed weight. Our findings confirmed the results reported by Seghatoleslami and Ahmadi Bonakdar ${ }^{46}$ that 1000 -seed weight is considered as one of the genetic traits of cultivars which is less affected by environmental factors such as temperature, light and moisture. The highest total seed yield was reached at 200,000 plants ha ${ }^{-1}$ level combined with $\mathrm{N}$ at $360 \mathrm{~kg} \mathrm{ha}^{-1}$ level. The total seed yield consists of the number of plants and seed yield per plant. This may be because high planting density produced more plant numbers and the effect of plant number on production was more than seed yield per plant.

The planting density at 200,000 plants $\mathrm{ha}^{-1}$ produced higher $\mathrm{N}$ uptake than at 120,000 plants $\mathrm{ha}^{-1}$ level. The competition for space, nutrients and light among plants grown at high density is always high. More nitrogen is needed to contribute to the competitiveness of plants. High planting density leads to overshadowing between different plants, hence much more $\mathrm{N}$ has to be assigned to light capture to compensate for the decrease in light 
intensity and to maintain photosynthesis ${ }^{14,47,48}$. Our results showed that at low planting density, higher nitrogen application rate had lower $\mathrm{N}$ uptake. It indicated that because the supply of nitrogen was in excess of plant requirement and possibility existed for loss of $\mathrm{N}$ by leaching and denitrification, Sesbania pea were unable to uptake $\mathrm{N}$ at the highest nitrogen application rate. Similar results were also reported by Khan et $a l .{ }^{44}$. Furthermore, at high planting density $\mathrm{N}$ uptake increased as nitrogen application rate increased. Similar results were found by El-Gizawy ${ }^{49}$, who reported that increasing nitrogen application rate up to $150 \mathrm{~kg} / \mathrm{fed}$ decreased agronomic nitrogen efficiency, apparent nitrogen recovery and increased $\mathrm{N}$ uptake in maize. Although crops absorbed more $\mathrm{N}$ at high nitrogen application rate, the absorbed $\mathrm{N}$ was used to increase the competition among plants, rather than obtain high crop yield. Thus, the management strategy of nitrogen should be determined according to both plant demand and plant $\mathrm{N}$ uptake, which in turn are determined by variety, planting density, soil conditions and other factors $^{50}$.

\section{Conclusion}

Planting density and nitrogen application rate significantly affected growth and yield of Sesbania pea, but had no significant effects on 1000-seed weight. The planting density of 120,000 plants ha $^{-1}$ promoted individual growth of Sesbania pea, while planting density of 200,000 plants ha ${ }^{-1}$ had higher dry weight and total seed yield. At 120,000 plants ha $^{-1}$ level and with $\mathrm{N}$ at $180 \mathrm{~kg} \mathrm{ha}^{-1}$ level showed the best effects on plant growth and seed yield of Sesbania pea. At 200,000 plants ha level, the optimum rate of nitrogen was $360 \mathrm{~kg} \mathrm{ha}^{-1}$ level.

1. Kumar, G. and Srivastava, N., Efficiency and effectiveness of gamma rays and sodium azide in Sesbania cannabina Poir. Cytologia, 2013, 78, 81-90.

2. Ye, Z. H., Yang, Z. Y., Chan, G. Y. S. and Wong, M. H., Growth response of Sesbania rostrata and S. cannabina to sludgeamended lead/zinc mine tailings: a greenhouse study. Environ. Int., 2001, 26, 449-455.

3. Li, Y. et al., Genetic diversity and community structure of rhizobia nodulating Sesbania cannabina in saline-alkaline soils. Syst. Appl. Microbiol., 2016, 39, 195-202.

4. Zhang, T. T., Zeng, S. L., Gao, Y., Ouyang, Z. T., Li, B., Fang, C. M. and Zhao, B., Assessing impact of land uses on land salinization in the Yellow River Delta, China using an integrated and spatial statistical model. Land Use Policy, 2011, 28, 857-866.

5. Cui, Y. C., Zhou, D. P. and Li, D. L., Progress of study on chemical modification and application of Sesbania gum. J. Henan Univ. (Nat. Sci.), 2004, 34(4), 30-33 (in Chinese with English abstract).

6. Roques, S. E. and Berry, P. M., The yield response of oilseed rape to plant population density. J. Agric. Sci., 2016, 154(2), 305320 .

7. Zandi, P., Shirani-Rad, A. H. and Bazrkar-Khatibani, L., Agronomic study of fenugreek grown under different in row spacing and nitrogen levels in a paddy field of Iran. Am.-Euras J. Agric. Environ. Sci., 2011, 10(4), 544-550.
8. Nasto, T. H., Balliu, A. and Zeka, N., The influence of planting density on growth characteristics and fruit yield of peppers (Capsicum annuит L.).. Acta Hortic., 2009, 830, 906-912.

9. Ozer, H., Sowing date and nitrogen rate effects on growth, yield and yield components of two summer rapeseed cultivars. Eur. J. Agron., 2003, 19, 453-463.

10. Ahmadi, M. and Bahrani, M. J., Yield and yield components of rapeseed as influenced by water stress at different growth stages and nitrogen levels. Am.-Euras. J. Agric. Environ. Sci., 2009, 5(6), $755-761$.

11. Li, Y. S. et al., High planting density benefits to mechanized harvest and nitrogen application rates of oilseed rape (Brassica napus L.). Soil Sci. Plant Nutr., 2014, 60(3), 384-392.

12. Xie, Y. H., An, S. Q., Wu, B. F. and Wang, W. W., Density-dependent root morphology and root distribution in the submerged plant Vallisneria natans. Environ. Exp. Bot., 2006, 57, 195-200.

13. Rossini, M. A., Maddonni, G. A. and Otegui, M. E., Inter-plant competition for resources in maize crops grown under contrasting nitrogen supply and density: variability in plant and ear growth. Field Crops Res., 2011, 121, 373-380.

14. Zhang, D. S. et al., Plant density affects light interception and yield in cotton grown as companion crop in young jujube plantations. Field Crops Res., 2014, 169, 132-139.

15. Bhuvaneswari, G., Sivaranjani, R., Reetha, S. and Ramakrishan, K., Application of nitrogen fertilizer on plant density, growth, yield and fruit of bell peppers (Capsicum annuиm L.). Int. Lett. Nat. Sci., 2014, 13, 81-90.

16. Ren, T., Liu, B., Lu, J. W., Deng, Z. H., Li, X. K. and Cong, R. $\mathrm{H}$., Optimal plant density and $\mathrm{N}$ fertilization to achieve higher seed yield and lower $\mathrm{N}$ surplus for winter oilseed rape (Brassica napus L.). Field Crops Res., 2017, 204, 199-207.

17. Siadat, S. A., Sadeghipour, O. and Hashemidezfouli, A. H., Effect of nitrogen and plant density on yield and yield component of rapeseed. J. Crop Prod. Res., 2010, 2(1), 49-62 (in Persian).

18. Bani-Saeedi, A., Examination of different amounts of nitrogen and density on growth, quantity and quality characters in canola, in Khozestan climate condition. MSc thesis, Dezfool University, Dezfool, Iran, 2001 (in Persian).

19. Tumbare, A. D. and Niikam, D. R., Effect of planting and fertigation on growth and yield of green chili (Capsicum annuиm). Indian J. Agric. Sci., 2004, 74, 242-245.

20. Sieling, K. and Kage, H., Efficient $\mathrm{N}$ management using winter oilseed rape. a review. Agron. Sustain Dev., 2010, 30, 271-279.

21. Zhang, W. J. et al., Effects of nitrogen application rate and ratio on lodging resistance of super rice with different genotypes. J. Int. Agric., 2013, 13, 63-72.

22. Majnoun-Hosseini, N., Alizadeh, H. M. and Malek-Ahmadi, H., Effects of plant density and nitrogen rates on the competitive ability of canola (Brassica napus L.) against weeds. J. Agric. Sci. Technol., 2006, 8, 281-291.

23. Mobasser, H. R., Shojaee-Ghadikolaee, M., Nasiri, M., Daneshian, J., Barari-Tari, D. and Pourkalhor, H., Effect of nitrogen rates and plant density on the agronomic traits of canola (Brassica napus L.) in paddy field. Asian J. Plant Sci., 2008, 7(2), 233-236.

24. Fathi, G., Bani-Saeidi, A., Siadat, S. A. and Ebrahimpour, F., Effect of different levels of nitrogen fertilizer and plant density on seed yield of colza cv. PF 7045 under Khuzestan province conditions. Sci. J. Agric. Shahid Chamran Univ., 2002, 25, 43-58.

25. Bremner, J. M. and Mulvaney, C. S., Nitrogen-total. In Methods of Soil Analysis (eds Page, A. L. et al.), Agronomy Monograph, Madisons, 1982, pp. 595-624.

26. Page, A. L., Millar, R. H. and Keeney, D. R., Methods of Soil Analysis: Part 2, American Society of Agronomy/Soil Science Society of America, Madison, Wisconsin, USA, 1982.

27. Mclean, E. O. and Watson, M. E., Soil measurements of plantavailable potassium. In Potassium in Agriculture (ed. Munson, 
R. D.), American Society of Agronomy, Madison, 1985, pp. $277-$ 308.

28. Tiessen, H. and Moir, J. O., Total and organic carbon. In Soil Sampling and Methods of Analysis. (ed. Carter, M. R.), Lewis Publ, Boca Raton, 1993, pp. 187-199.

29. Hendershot, W. H., Lalande, H. and Duquette, M., Ion exchange and exchangeable cations. In Soil Sampling and Methods of Analysis (ed. Carter, M. R.), Lewis Publ, Boca Raton, 1993, pp. $167-$ 176.

30. Lu, M. Y., Study on the methods of soil salt content determination. Chin. J. Soil Sci., 1982, 2, 36-39 (in Chinese).

31. Ozer, H., The effect of plant population densities on growth, yield and yield components of two spring rapeseed cultivars. Plant Soil Environ., 2003, 49, 422-426.

32. Gomez, K. A. and Gomez, A. A., Statistical Procedures for Agricultural Research, John Wiley, New York, USA, 1984, 2nd edn.

33. Aminifard, M. H., Aroiee, H., Ameri, A. and Fatemi, H., Effect of plant density and nitrogen fertilizer on growth, yield and fruit quality of sweet pepper (Capsicum annuum L.). Afr. J. Agric. Res., 2012, 7, 859-866.

34. EI-Gizawy, N. K. B., Effects of nitrogen rate and plant density on agronomic nitrogen efficiency and maize yields following wheat and faba bean. Am.-Euras J. Agric. Environ. Sci., 2009, 5, 378 386.

35. Forbes, J. C. and Watson, R. D., Plants in Agriculture, Cambridge University Press, Cambridge, UK, 1994, 2nd edn.

36. Samih, A., Effect of plant density on flowering date, yield and quality attribute of bush beans (Phaseolus vulgaris L.) under centre pivot irrigation system. Am. J. Agric. Biol. Sci., 2008, 3(4), 666-668.

37. Amanullah, H., Marwat, K. B., Shah, P., Maula, N. and Arifullah, S., Nitrogen levels and its time of application influence leaf area, height and biomass of maize planted at low and high density. Pak. J. Bot., 2009, 41, 761-768.

38. Marschner, H., Mineral Nutrition of Higher Plants, Academic Press, London, UK, 1995.

39. Basela, O. and Mahadeen, A., Effect of fertilizers on growth, yield, yield components, quality and certain nutrient contents in broccoli (Brassica oleracea). J. Agric. Biol., 2008, 10, 627-632.

40. Loecke, T. D., Liebman, M., Cambardella, C. A. and Richard, T. L., Corn response to composting and time of application of solid swine manure. Agron. J., 2004, 96, 214-223.

41. Toghraei, A., Shirani Rad, A. H., Valadabadi, A. R. and ZareiKooshki, M., Effect of plant density and nitrogen consumption on some agronomical characteristics of peppermint (Mentha pipertia L.). In Research in Agriculture. Islamic Azad University (Takestan Branch), Iran, 2009, 1(2), pp. 57-65.
42. Takebe, M., Ishihara, T., Matsuna, K., Fojimoto, J. and Yoneyama, T., Effect of nitrogen application on the contents of sugars, ascorbic acid, nitrate and oxalic acid in spinach (Spinacia oleracea L.) and komatsuna (Brassica campestris L.). Jpn. J. Soil Sci. Plant Nutr., 1995, 66, 238-246.

43. Lin, X. Q., Zhu, D. F., Chen, H. Z., Cheng, S. H. and Uphoff, N., Effect of plant density and nitrogen fertilizer rates on grain yield and nitrogen uptake of hybrid rice (Oryza sativa L.). J. Agric. Biotech. Sustain. Develop., 2009, 1, 044-053.

44. Khan, S., Anwar, S., Kuai, J., Ullah, S., Fahad, S. and Zhou, G. S., Optimization of nitrogen rate and planting density for improving yield, nitrogen use efficiency, and lodging resistance in oilseed rape. Front. Plant Sci., 2017, 8, 532.

45. Khadem Hamzeh, H. R., Karimie, M., Rezaie, A. and Ahmadie, M., Effect of plant density and planting date on agronomic characteristics, yield and yield components in soybean. Iran. J. Agric. Sci., 2004, 35, 357-367.

46. Seghatoleslami, M. J. and Ahmadi Bonakdar, K. H., The effect of sowing date and plant density on yield and yield componets of fenugreek (Trigonella foenum graecum L.). Iran. J. Med. Aromat. Plants, 2010, 26, 265-274.

47. Kitaoka, S. and Koike, T., Invasion of broad-leaf tree species into a larchplantation: seasonal light environment, photosynthesis and nitrogen allocation. Physiol. Plant., 2004, 121, 604-611.

48. Delagrange, S., Light and seasonal induced plasticity in leaf morphology, $\mathrm{N}$ partitioning and photosynthetic capacity of two temperate deciduous species. Environ. Exp. Bot., 2011, 70, $1-10$.

49. El-Gizawy, N. Kh. B., Effect of irrigation intervals, nitrogen rates and spraying with zinc on yield, uptake and agronomic efficiency of nitrogen in maize. Ann. Agric. Sci. Moshtohor., 2005, 43, 10071020 .

50. D'Andrea, K. E, Otegui, M. E. and Cirilo, A. G., Kernel number determination differs among maize hybrids in response to nitrogen. Field Crops Res., 2008, 105, 228-239.

ACKNOWLEDGEMENTS. This study was supported in part by the Jiangsu Provincial Key R\&D Program (BE2016345), Jiangsu Provincial Agricultural Innovation Fund (CX16(1005)), the Priority Academic Program Development of Jiangsu Higher Education Institution, and Natural Science Foundation of Jiangsu Higher Education Institutions of China (No. 17KJB210008).

Received 10 July 2018; revised accepted 15 November 2018

doi: $10.18520 / \mathrm{cs} / \mathrm{v} 116 / \mathrm{i} 5 / 758-764$ 